DOI: $10.20472 /$ IAC.2019.049.042

\author{
PIOTR WAZŻ \\ Medical University of Gdańsk, Poland \\ DOROTA BIELIŃSKA-WAZŻ \\ Medical University of Gdańsk, Poland \\ AGNIESZKA BIELIŃSKA \\ Medical University of Gdańsk, Poland \\ JOANNA CIESZYŃSKA \\ Municipal Hospital St Vincent a Paulo, Poland \\ MIKOŁAJ MAJKOWICZ \\ Pomeranian University in Słupsk, Poland
}

\title{
SIMILARITY MAPS IN VARIOUS AREAS OF SCIENCE
}

\begin{abstract}
:
The aim of the present work are similarity/dissimilarity studies in bioinformatics as well as in social and health sciences. The considered objects have very diverse characters. They are biological sequences in bioinformatics and groups of individuals and their answers to some questions in the case of health and social sciences. In particular, we present a new bioinformatics method in which the biological sequences are represented by 3D-dynamic graphs [1]. For comparison of such objects we apply values analogous to these used in the classical dynamics. This method is a generalization of the 2D method [2]. Similarity is relative: it depends on the properties being considered. Examples of similarity maps for different properties (factors) in social science [3,4], in bioinformatics [1], and unpublished results in the health sciences are shown. In this way, we can classify different objects and search for factors which influence the results of the classifications.
\end{abstract}

[1] P. Wąż, D. Bielińska-Wąż, 3D-dynamic Representation of DNA Sequences, Journal of Molecular Modeling 20 (2014) art. ID 2141, 1-7.

[2] P. Wąż, D. Bielińska-Wąż, A. Nandy, Descriptors of 2D-dynamic Graphs as a Classification Tool of DNA Sequences, Journal of Mathematical Chemistry 52 (2014) 132-140.

[3] A. Bielińska, M. Majkowicz, P. Wąż, D. Bielińska-Wąż, Overall Quality of Life and General Health Changes Related to the Retirement Threshold, eTELEMED 2018, The Tenth International Conference on eHealth, Telemedicine, and Social Medicine, Rome, Italy, 2018, XPS IARIA Press, eTELEMED 2018 Proceedings, eds. Y. Murata et al., pp. 1-5.

[4] A. Bielińska, M. Majkowicz, P. Wąż, D. Bielińska-Wąż, Mathematical Modeling: Interdisciplinary Similarity Studies, in "Numerical Methods and Applications", eds. G. Nikolov et al., Lecture Notes in Computer Science vol. 11189, pp. 334-341, Springer, 2019.

\section{Keywords:}

computational methods, clustering, bioinformatics, quality of life 
JEL Classification: C02 